\title{
A Study of Nitrogenase Activity in Mycoplana Species and Free-living Actinomycetes
}

\author{
By H. W. PEARSON, ${ }^{*}$ R. HOWSLEY AND S. T. WILLIAMS \\ Department of Botany, University of Liverpool, P.O. Box 147, Liverpool L69 3BX, U.K.
}

(Received 4 January 1982)

\begin{abstract}
A range of actinomycetes and Mycoplana strains were screened for nitrogenase activity. No positive results were obtained with actinomycetes, although some grew on media without added combined nitrogen. In contrast, most Mycoplana strains showed nitrogenase activity. Although the strains were unable to grow in anaerobic conditions, sustained nitrogen fixation required microaerobic conditions. The relationship of Mycoplana to actinomycetes is discussed.
\end{abstract}

\section{INTRODUCTION}

It has been known for many years that actinomycete-like organisms fix dinitrogen in the nodules of various non-leguminous plants. These organisms have been placed in the genus Frankia.

Several successful isolations of Frankia endophytes have been reported, for example from Comptonia peregrina (Callaham et al., 1978), Alnus glutinosa (Quispel \& Tak, 1978), Myrica pensylvanica (Lechevalier \& Lechevalier, 1979), Elaeagnus umbellata (Baker et al., 1979; Baker \& Torrey, 1979), Alnus viridis (Baker et al., 1979) and A. rubra (Berry \& Torrey, 1979). With the exception of the Elaeagnus umbellata isolate, all were shown to re-infect host plant seedlings and produce effective $\mathrm{N}_{2}$-fixing root nodules. Most current information on dinitrogen fixation by Frankia has come from studies with particulate nodule homogenates (Akkermans et al., 1977; Van Straten et al., 1977; Benson \& Eveleigh, 1979), or active cell-free extracts of actinorhizal roots (Benson et al., 1979). However, recently, nitrogenase activity has been demonstrated in vitro in pure cultures of Frankia (Tjepkema et al., 1980; Gauthier et al., 1981).

In contrast, there is no definitive evidence for nitrogenase activity in free-living actinomycetes. Dinitrogen fixation by Nocardia calcarea and $N$. cellulans was reported by Metcalfe \& Brown (1957) but this was repudiated by Hill \& Postgate (1969). Unequivocal evidence for nitrogenase activity in an organism originally called Mycobacterium flavum was obtained by Biggins \& Postgate (1969). However, subsequent studies showed that $M$. flavum was incorrectly classified as an actinomycete (Biggins \& Postgate, 1971) and it was renamed Xanthobacter flavus, a new species of the hydrogen bacteria (Malik \& Claus, 1979).

In this study we have tested a range of free-living actinomycetes for nitrogenase activity under various experimental conditions. Mycoplana species were also included as they have been regarded as members of the Actinomycetales because of their abundant branching (Sukapure et al., 1970).

\section{METHODS}

Test organisms and inoculum preparation. The actinomycetes were stored as spores or mycelial macerates in $10 \%$ (v/v) glycerol at $-20^{\circ} \mathrm{C}$ (Wellington \& Williams, 1978). Actively growing cultures were produced by inoculation of the thawed glycerol suspensions on to nutrient agar (Oxoid no. 3) or oatmeal agar (Küster, 1959). The Mycoplana strains were stored as freeze-dried samples and activated by inoculation on to Bennett's medium (Jones, 1949) solidified with $1 \%(\mathrm{w} / \mathrm{v})$ agar. Cultures were incubated at $28^{\circ} \mathrm{C}$ for 3 to $7 \mathrm{~d}$ to provide the inoculum for studies on growth and nitrogenase activity.

Initial screening for nitrogenase activity. The medium designated AM50, contained $\left(\mathrm{g}^{-1}\right):$ glucose, $10 \cdot 0 ;$ sodium succinate, $2 \cdot 0 ; \mathrm{K}_{2} \mathrm{HPO}_{4}, 1 \cdot 0 ; \mathrm{KCl}, 0 \cdot 5 ; \mathrm{MgSO}_{4} .7 \mathrm{H}_{2} \mathrm{O}, 0 \cdot 5 ;\left(\mathrm{NH}_{4}\right)_{2} \mathrm{SO}_{4}, 0 \cdot 236$ (i.e. $\left.50 \mathrm{mg} \mathrm{N} \mathrm{1-1}\right) ; \mathrm{FeSO}_{4} .2 \mathrm{H}_{2} \mathrm{O}$, 
$0.01 ; \mathrm{Na}_{2} \mathrm{MoO}_{4} \cdot 2 \mathrm{H}_{2} \mathrm{O}, 0.005 ; \mathrm{pH} 7 \cdot 0-7 \cdot 3$. When $\left(\mathrm{NH}_{4}\right)_{2} \mathrm{SO}_{4}$ was omitted the medium was termed AM0. Both media were used in liquid form and with agar $(1 \cdot 2 \% \mathrm{w} / \mathrm{v})$.

All test strains were initially inoculated into liquid AM50 medium in $100 \mathrm{ml}$ Erlenmeyer flasks and incubated at $28{ }^{\circ} \mathrm{C}$ with shaking. After 7 to $10 \mathrm{~d}$ growth, these cultures were used as inocula in screening experiments for nitrogenase activity as follows. Inocula of all the test strains were streaked on to slopes of AM50 and AM0 media contained in McCartney vials fitted with serum caps and grown under $\mathrm{pO}_{2}$ of $0,0.025,0.05,0.10$ and $0.20 \mathrm{~atm}(1$ atm $=101.32 \mathrm{kPa}$ ) in $\mathrm{N}_{2}$. The gas phase in each vial was renewed every day. In addition, the test strains were also inoculated into AM0 and AM50 liquid media and incubated aerobically as static and shake cultures. After 2, 5, 10 and $15 \mathrm{~d}$ incubation, the presence or absence of growth was noted and nitrogenase activity determined.

A modified acetylene reduction technique was used to estimate nitrogenase activity (Stewart $e t$ al., 1971). Samples ( $3 \mathrm{ml}$ ) from liquid cultures were transferred (with minimum disturbance), to McCartney vials fitted with serum caps. Cultures already growing in vials were assayed in situ. Acetylene was injected into the vials to $10 \%$ (v/v). They were then incubated at $28^{\circ} \mathrm{C}$ on an orbital shaker (80-120 rev. $\mathrm{min}^{-1}, 2-3 \mathrm{~cm}$ amplitude) except for samples of the static-grown liquid cultures, which were gently swirled immediately after the addition of acetylene and then left to stand. Vials containing either samples of the test organisms or pure media, to which no acetylene had been added, were also incubated under the various experimental conditions. These controls were to check for any extraneous ethylene production. After 1, 6 and $24 \mathrm{~h}, 1 \mathrm{ml}$ samples of the gas phase in each of the vials were removed and analysed for ethylene and acetylene using a Perkin-Elmer F11 gas chromatograph (oven temperature $60{ }^{\circ} \mathrm{C}$ ) fitted with a $0.5 \mathrm{~m} 80-100$ mesh Porapak T column.

${ }^{15} \mathrm{~N}$ tracer studies. One of the strains which gave a positive reaction with the acetylene reduction test (Mycoplana dimorpha LL-C4) was selected for confirmatory testing using the ${ }^{15} \mathrm{~N}$ tracer technique. The methods of Rai (1980) were used for the exposure of $15 \mathrm{ml}$ samples of aerobic static-grown liquid cultures (in AM0 medium) to ${ }^{15} \mathrm{~N}$ gas in McCartney vials and for their subsequent digestion and analysis. The samples were incubated for $2 \mathrm{~h}$ at $26^{\circ} \mathrm{C}$ under a gas phase comprising $\mathrm{N}_{2} / \mathrm{A} / \mathrm{CO}_{2}(30: 69 \cdot 96: 0 \cdot 04$, by vol.) with a 60 atom $\%$ enrichment of the nitrogen with ${ }^{15} \mathrm{~N}$. Controls comprised sterile AM0 medium exposed to the ${ }^{15} \mathrm{~N}$ enriched gas phase and samples of Mycoplana incubated under the gas phase without ${ }^{15} \mathrm{~N}$ enrichment. A VG Micromass 601 mass spectrometer was used to analyse for ${ }^{15} \mathrm{~N}$ enrichment.

Effect of carbon sources on nitrogenase activity. A range of carbon sources (see Results) were substituted for the glucose/succinate combination in media AM50 and AM0. Mycoplana dimorpha LL-C4 was inoculated into $15 \mathrm{ml}$ of the variously substituted liquid media contained in McCartney vials and incubated aerobically at a $\mathrm{pO}_{2}$ of 0.05 atm at $28{ }^{\circ} \mathrm{C}$ with shaking. Growth was estimated after 4 and $7 \mathrm{~d}$ by measuring the increase in turbidity of samples removed from the cultures at $540 \mathrm{~nm}$ using a Pye Unicam SP600 spectrophotometer. Nitrogenase activity was determined in the substituted AM0 series and after 2 and $4 \mathrm{~d}$. The samples were incubated with acetylene for 1 and $6 \mathrm{~h}$.

Effect of different oxygen concentrations on nitrogenase activity. The influence of a range of sub-atmospheric oxygen concentrations on nitrogenase activity by Mycoplana dimorpha LL-C4 was studied. Samples of a dilute $\mathrm{N}_{2}-$ fixing liquid culture grown at a $\mathrm{pO}_{2}$ of 0.05 atm were dispensed into McCartney vials fitted with serum caps. These were exposed with shaking at $28^{\circ} \mathrm{C}$ to $\mathrm{pO}_{2}$ in the range 0 to $0.1 \mathrm{~atm}$. Nitrogenase activity in replicate vials was followed during a $4 \mathrm{~h}$ exposure to the oxygen regimes. Longer-term effects were studied by exposing cells to $\mathrm{pO}_{2}$ in the range 0 to $0 \cdot 1 \mathrm{~atm}$ for periods of 20 and $40 \mathrm{~h}$.

The influence of changing oxygen regimes on nitrogenase activity was also investigated. Cultures grown under a $\mathrm{pO}_{2}$ of $0.05 \mathrm{~atm}$ were either: (i) incubated under pure nitrogen for $40 \mathrm{~h}$ and then flushed with a gas mixture with a $\mathrm{pO}_{2}$ of $0.025 \mathrm{~atm}$, or (ii) incubated under a $\mathrm{pO}_{2}$ of $0.025 \mathrm{~atm}$ for $40 \mathrm{~h}$ and then reflushed with the same gas mixture or with pure nitrogen, or (iii) incubated under a $\mathrm{pO}_{2}$ of $0.05 \mathrm{~atm}$ for $40 \mathrm{~h}$ and then reflushed with the same gas mixture or with pure nitrogen.

Where rates of acetylene reduction are expressed on a dry weight basis, samples of the cultures were filtered on to $2.5 \mathrm{~cm}$ diameter GS type membranes (Millipore), pore size $0.22 \mu \mathrm{m}$, and dried to constant weight at $90^{\circ} \mathrm{C}$.

Effect of different ammonium and nitrate concentrations on growth and activity. One $\mathrm{ml}$ quantities of freshly prepared filter-sterilized stock solutions of $\left(\mathrm{NH}_{4}\right)_{2} \mathrm{SO}_{4}$ or $\mathrm{KNO}_{3}$ were added to sterile AM0 liquid medium contained in Erlenmeyer flasks to give known final concentrations in the range 0 to $150 \mathrm{mg} \mathrm{N}^{-1}$. The flasks were inoculated with a uniform suspension of Mycoplana dimorpha LL-C4 and incubated at $28^{\circ} \mathrm{C}$ for up to $10 \mathrm{~d}$, either aerobically in static and shake culture, or at a $\mathrm{pO}_{2}$ of $0.05 \mathrm{~atm}$. Growth was estimated spectrophotometrically and nitrogenase activity by the acetylene reduction technique.

\section{RESULTS}

Screening of actinomycetes and Mycoplana strains for nitrogenase activity

The defined medium containing ammonium (AM50) supported growth of all strains, but few strains were able to grow on the medium lacking combined nitrogen (AM0) (Table 1). Single 
Table 1. Screening of actinomycetes and Mycoplana strains for growth in the absence of combined nitrogen, and for nitrogenase activity

\begin{tabular}{|c|c|c|}
\hline Strain* & $\begin{array}{l}\text { Growth in medium } \\
\text { lacking combined } \\
\text { nitrogen (AM0)† }\end{array}$ & $\begin{array}{c}\text { Nitrogenase } \\
\text { activity } \\
\text { (in } \mathrm{AM} 50 \text { or } \mathrm{AM} 0)_{\ddagger}^{+}\end{array}$ \\
\hline Nocardia asteroides ATCC 19247 & - & - \\
\hline N. asteroides NCTC 8595 & - & - \\
\hline$N$. asteroides N671 & - & - \\
\hline N. autotrophica NCIB 9574 & - & - \\
\hline N. brasiliensis ATCC 19296 & + & - \\
\hline N. calcarea NCIB 8863 & - & - \\
\hline N. opaca CBS 330 & - & - \\
\hline N. opaca NCIB 9409 & + & - \\
\hline N. otitidis-caviarum Mariat 751 & - & - \\
\hline$N$. pellegrino ATCC 15998 & - & - \\
\hline N. saturnea ATCC 15778 & - & - \\
\hline Nocardioides albus IMET 7801 & - & - \\
\hline Oerskovia turbata IMET 7153 & + & - \\
\hline O. xanthineolytica LL-Y13-3 & - & - \\
\hline Rhodococcus coprophilus CUB 628 & - & - \\
\hline R. coprophilus CUB 118 & - & - \\
\hline$R$. corallinus ATCC 60004 & - & - \\
\hline R. erythropolis NCIB 9158 & - & - \\
\hline R. ruber $\mathrm{N} 361$ & - & - \\
\hline Streptomyces aureofaciens NRRL B-1286 & - & - \\
\hline S. michiganensis ATCC 14970 & - & - \\
\hline S. violaceoruber ATCC 14980 & - & - \\
\hline$S$. viridochromogenes CBS & - & - \\
\hline Streptomyces sp. soil isolate M1 & + & - \\
\hline Streptomyces sp. soil isolate F1 & - & - \\
\hline Streptomyces $\mathrm{sp}$. soil isolate $\mathrm{Cl}$ & + & - \\
\hline Streptomyces $\mathrm{sp}$. soil isolate $\mathrm{T} 1$ & - & - \\
\hline Mycoplana dimorpha LL-C4 & + & + \\
\hline$M$. dimorpha LL-C3 & + & + \\
\hline M. dimorpha LL-4-9 & + & + \\
\hline M. dimorpha LL-5-20 & + & + \\
\hline M. dimorpha LL-8-32 & + & + \\
\hline M. dimorpha LL-100-32 & + & + \\
\hline M. dimorpha NCIB 9439 & + & + \\
\hline M. dimorpha ATCC 4279 & - & - \\
\hline M. bullata NCIB 9440 & + & + \\
\hline M. bullata ATCC 4278 & - & - \\
\hline
\end{tabular}

* Sources: ATCC, American Type Culture Collection, Rockville, Maryland, U.S.A.; CBS, Centraalbureau voor Schimmelcultures, Baarn, Netherlands; CUB, Dr T. Cross, School of Biological Sciences, University of Bradford, Bradford, W. Yorks., U.K.; IMET, Institute for Microbiology and Experimental Therapy, Jena, G.D.R.; LL, Dr M. P. Lechevalier, Waksman Institute of Microbiology, Rutgers University, New Jersey, U.S.A.; M. Mariat, Institut Pasteur, Paris, France; N, Dr M. Goodfellow, Microbiology Department, University of Newcastle, U.K.; NCIB, National Collection of Industrial Bacteria, Aberdeen, U.K.; NCTC, National Collection of Type Cultures, London, U.K.; NRRL, Northern Regional Research Laboratory, U.S. Department of Agriculture, Peoria, Ill., U.S.A.

+ Strains are listed positive if growth on AM0 occurred under any of the incubation conditions described in Methods.

¥ Strains are listed as positive if nitrogenase activity was measurable under any of the incubation conditions described in Methods.

strains of Nocardia brasiliensis, $N$. opaca, Oerskovia turbata, and two Streptomyces isolates, were able to grow on solidified AM0 medium. However, none of these strains showed nitrogenase activity even when grown and assayed under sub-atmospheric oxygen concentrations. They, presumably, were able to utilize traces of combined nitrogen carried over at inoculation, or present in the agar or gas phase. In contrast, most strains of Mycoplana grew on AM0 and showed nitrogenase activity under aerobic conditions and at $\mathrm{pO}_{2}$ values below $0.2 \mathrm{~atm}$ as indicated by the acetylene reduction technique. 


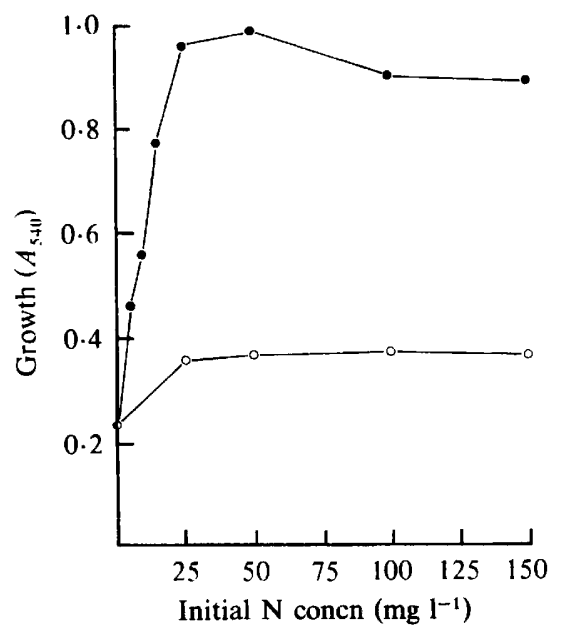

Fig. 1. Growth of Mycoplana dimorpha LL-C4 in aerobic shake culture in liquid media containing different concentrations of $\left(\mathrm{NH}_{4}\right)_{2} \mathrm{SO}_{4}(\mathrm{O})$ and $\mathrm{KNO}_{3}(\mathrm{O})$.

\section{Dinitrogen fixation by Mycoplana}

One of the strains showing nitrogenase activity, Mycoplana dimorpha LL-C4, was selected for more detailed study.

Nitrogen fixation by $M$. dimorpha LL-C4 was confirmed by the ${ }^{15} \mathrm{~N}$ tracer technique. Samples of an aerobically-grown static liquid culture exposed to ${ }^{15} \mathrm{~N}_{2}$ under anaerobic conditions for $2 \mathrm{~h}$ showed a mean atom $\%{ }^{15} \mathrm{~N}$ enrichment of 0.430 , compared with a natural enrichment of 0.366 in control samples of Mycoplana which were not exposed to the ${ }^{15} \mathrm{~N}$ gas phase.

The influence of various factors on nitrogenase activity in $M$. dimorpha LL-C4 was also studied. Growth and nitrogenase activity were optimal at $30^{\circ} \mathrm{C}\left( \pm 2{ }^{\circ} \mathrm{C}\right)$ and between $\mathrm{pH} 6.5$ and 7.5. Good growth and nitrogenase activity occurred when L-arabinose, ethanol, D-glucose, sodium lactate or sodium succinate were provided as sole carbon sources. In contrast, D-fructose, maltose and sucrose gave poor growth and nitrogenase activity. The cell yield of $M$. dimorpha (LL-C4) increased exponentially with increasing concentrations of ammonium up to $50 \mathrm{mg} \mathrm{N}$ $\mathrm{1}^{-1}$ (Fig. 1) and growth was always better on ammonium than in combined-nitrogen-free medium, regardless of the oxygen regime. An ammonium concentration of $15 \mathrm{mg} \mathrm{N}^{-1}$ totally suppressed nitrogenase activity. In contrast, concentrations of nitrate up to $150 \mathrm{mg} \mathrm{N}^{-1}$ did not support substantially greater growth than that obtained in combined-nitrogen-free cultures. Preliminary screening studies suggested that nitrogenase activity in Mycoplana cultures might be stimulated by sub-atmospheric concentrations of molecular oxygen, a view also supported by the observation that cultures with good levels of nitrogenase activity could be more reliably produced by growing them at an initial $\mathrm{pO}_{2}$ of $0.05 \mathrm{~atm}$ rather than in air. The influence of oxygen concentration on nitrogenase activity was therefore investigated further. Nitrogenase activity in $M$. dimorpha LL-C4 previously grown at a $\mathrm{pO}_{2}$ of 0.05 atm was progressively stimulated by decreasing oxygen concentrations over a $4 \mathrm{~h}$ period (Fig. 2). Little activity was detected at oxygen concentrations above $0.06 \mathrm{~atm}$.

However, Mycoplana dimorpha LL-C4 was not able to grow in slope or stab cultures incubated under anaerobic conditions. Therefore, cultures were incubated under a range of oxygen concentrations for 20 and $40 \mathrm{~h}$ and then assayed for nitrogenase activity. There was no activity in the absence of oxygen and the highest rates occurred at 0.025 atm oxygen (Fig. 3). Loss of nitrogenase activity with prolonged incubation under anaerobic conditions was reversible. Samples from a culture grown under a $\mathrm{pO}_{2}$ of 0.05 atm were transferred to anaerobic conditions for $40 \mathrm{~h}$; nitrogenase activity was re-established after a short lag by transfer to $0.025 \mathrm{~atm}$ oxygen (Fig. $4 a$ ). When samples of the culture grown under $0.05 \mathrm{~atm}$ oxygen were transferred to $0.025 \mathrm{~atm}$, nitrogenase activity was initially high. The decline in activity after $40 \mathrm{~h}$ was temporarily 


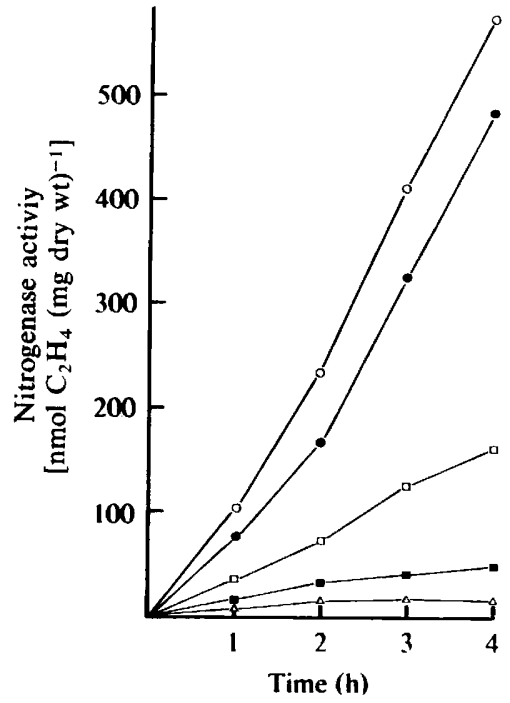

Fig. 2

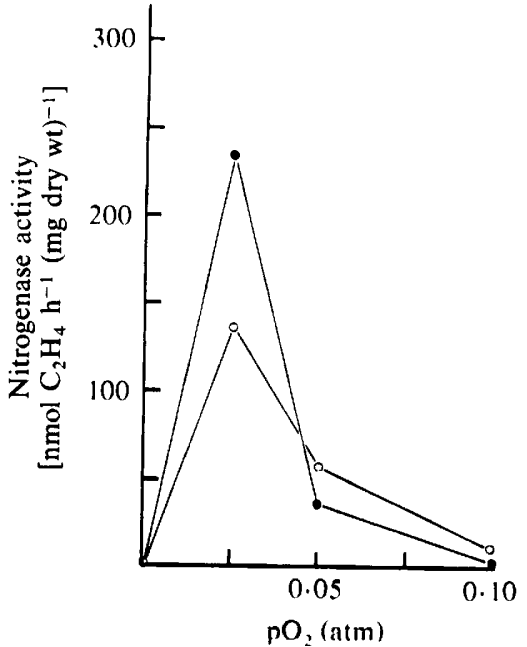

Fig. 3

Fig. 2. Nitrogenase activity by Mycoplana dimorpha LL-C4 grown at a $\mathrm{pO}_{2}$ of 0.05 atm and then incubated at $\mathrm{pO}_{2}$ of $0.00(0) ; 0.02(0) ; 0.04(\square) ; 0.06(\square)$ and $0.08(\triangle)$ atm. Values are the means of at least triplicate determinations.

Fig. 3. Nitrogenase activity by Mycoplana dimorpha LL-C4 grown at a $\mathrm{pO}_{2}$ of 0.05 atm and then incubated at different $\mathrm{pO}_{2}$ for $20 \mathrm{~h}(\mathrm{O})$ and $40 \mathrm{~h}(\mathrm{O})$. Values are the means of at least triplicate determinations.
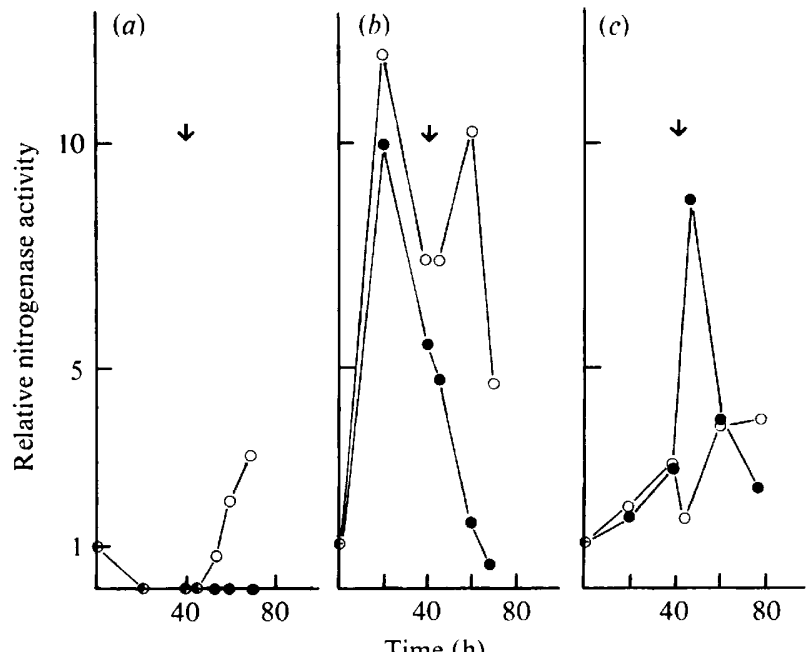

Fig. 4. Nitrogenase activity by Mycoplana dimorpha LL-C4 grown under a $\mathrm{pO}_{2}$ of 0.05 atm and then: (a) transferred to and, after $40 \mathrm{~h}$, either retained under pure nitrogen ( $O$ ) or reflushed with a gas mixture with a $\mathrm{pO}_{2}$ of $0.025 \mathrm{~atm}(\mathrm{O})$; (b) transferred to a $\mathrm{pO}_{2}$ of 0.025 atm and then, after $40 . \mathrm{h}$, either reflushed with a gas mixture with a $\mathrm{pO}_{2}$ of 0.025 atm oxygen $(O)$, or reflushed with pure nitrogen $(O)$; $(c)$ retained under a $\mathrm{pO}_{2}$ of $0.05 \mathrm{~atm}$ and, after $40 \mathrm{~h}$, either reflushed with the same gas mixture $(O)$ or reflushed with pure nitrogen $(O)$. The arrows show the point at which the gas phases were changed. Values are the means of at least triplicate determinations. 
reversed by reflushing with a gas mixture with a $\mathrm{pO}_{2}$ of 0.025 atm oxygen, but not by reflushing with pure nitrogen (Fig. $4 b$ ). If samples from the culture grown under $0.05 \mathrm{~atm}$ oxygen were maintained at this oxygen tension and reflushed with the same gas mixture after $40 \mathrm{~h}$, the steady increase in nitrogenase activity was resumed after a short initial drop in the rate immediately after reflushing (Fig. 4c). However, when samples were reflushed with nitrogen instead of 0.05 atm oxygen, there was a short-term stimulation of nitrogenase activity, but the rate then dropped below that in the samples maintained under 0.05 atm oxygen.

These results suggest that although nitrogenase activity is optimum under anaerobic conditions in the short-term, it is dependent on reductant and/or ATP generated by aerobic respiration. Under the experimental conditions used here, an oxygen concentration of approximately $0.025 \mathrm{~atm}$ appears best to drive aerobic respiration at a rate sufficient to meet the energy requirements of nitrogen fixation, while not disturbing the oxygen protection mechanism of the nitrogenase complex. The nitrogenase activity detected in Mycoplana strains grown on solid medium or in static liquid culture under aerobic conditions could be explained by decreased oxygen tensions within the mass of the individual colonies or in the liquid medium as a result of respiratory activity. Nitrogenase activity in samples of aerobic static liquid cultures of $\mathrm{Myco}$ plana dimorpha LL-C4 was lost by vigorous shaking in air.

\section{DISCUSSION}

It has been shown for the first time that species of the genus Mycoplana are capable of dinitrogen fixation. The rates of acetylene reduction (Fig. 3) are low compared with those for other free-living bacteria, but higher than values reported for liquid cultures of free-living Rhizobium sp. 'cowpea' strain 32 H1 (Tjepkema \& Evans, 1975). Although Mycoplana species are apparently obligate aerobes, sustained nitrogenase activity is dependent on the maintenance of microaerobic conditions. Little is known about the ecology of this genus, but most strains originate from soil, where they probably represent another component of the free-living, nitrogen-fixing population.

Nitrogenase activity was demonstrated in eight Mycoplana strains, including type cultures of $M$. dimorpha (NCIB 9439) and $M$. bullata (NCIB 9440). The genus was erected by Gray \& Thornton (1928) and these cultures were deposited by the senior author. However, the two cultures deposited in the American collection ( $M$. dimorpha ATCC 4279, $M$. bullata ATCC 4278) failed to show nitrogenase activity. Therefore, the strains from NCIB and ATCC are either different, or the latter have lost the facility to express nitrogenase activity.

Mycoplana strains were originally included in this study because some workers have included the genus in the Actinomycetales (Gray \& Thornton, 1928; Sukapure et al., 1970; Cross \& Goodfellow, 1973). However, the relationship of these Gram-negative, motile, branching bacteria to actinomycetes is questionable. In the 7th edition of Bergey's Manual of Determinative Bacteriology, Mycoplana was placed in the Pseudomonadaceae (Breed \& Smith, 1957); it was omitted from the 8th edition (Buchanan \& Gibbons, 1974). Results from their DNA-RNA hybridization studies on $M$. dimorpha NCIB 9439 and $M$. bullata NCIB 9440 led De Smedt \& De Ley (1977) to conclude that these organisms were remote relatives of the family Rhizobiaceae, which contains many nitrogen-fixing species. However, the taxonomic implications of nitrogenase activity should not be over-estimated as it occurs in free-living, aerobic bacteria which belong to different rRNA superfamilies (De Smedt et al., 1980).

Nitrogenase activity was not detected in any of the strains which are unequivocally actinomycetes, even when growth was initially stimulated by the addition of ammonia and incubation carried out under sub-atmospheric $\mathrm{pO}_{2} \mathrm{~s}$. Most common soil genera were represented, including Nocardia calcarea NCIB 8863 in which Hill \& Postgate (1969) were also unable to detect nitrogenase activity, despite an earlier claim that it fixed dinitrogen (Metcalfe \& Brown, 1957). A few strains grew on agar media without added combined nitrogen but further testing of these at low $\mathrm{pO}_{2}$ with the various carbon sources which supported growth and nitrogenase in $M y c o-$ plana dimorpha LL-C4 still failed to stimulate nitrogenase activity. Thus, although Frankia 
species fix nitrogen when growing as root endophytes and in vitro, there is still no clear evidence that free-living actinomycetes have this ability.

It is hoped that the demonstration of nitrogenase activity in Mycoplana will stimulate further studies on the physiology and ecology of this neglected genus.

We thank Mr P. Green (Torry Research Station, Aberdeen) and Dr M. P. Lechevalier (Waksman Institute of Microbiology, Rutgers University, New Jersey, U.S.A.) for advice and cultures. We also thank Dr A. N. Rai (Department of Biological Sciences, University of Dundee) for assistance with the ${ }^{15} \mathrm{~N}$ studies. This work was supported by a research grant from the University of Liverpool.

\section{REFERENCES}

Akkermans, A. D. L., Van Straten, J. \& Roelofsen, W. (1977). Nitrogenase activity of nodule homogenates of Alnus glutinosa: a comparison with the Rhizobium-pea system. In Recent Developments in Nitrogen Fixation, pp. 591-603. Edited by W. E. Newton, J. R. Postgate \& C. Rodriguez-Barrucce. London: Academic Press.

BAKER, D. \& TORREY, J. G. (1979). In Symbiotic Nitrogen Fixation in the Management of Temperate Forests, pp. 38-56. Edited by J. C. Gordon, C. T. Wheeler \& D. A. Perry. Corvallis: Oregon State University Press.

BAKER, D., Torrey, J. G. \& KIDD, G. H. (1979). Isolation by sucrose-density fractionation and cultivation in vitro of actinomycetes from nitrogen fixing root nodules. Nature, London 281, 76-77.

Benson, D. R. \& Eveleigh, D. E. (1979). Nitrogenfixing homogenates of Myrica pensylvanica (Bayberry) non-legume root nodules. Soil Biology and Biochemistry 11, 331-334.

Benson, D., ARP, D. J. \& Burris, R. H. (1979). Cellfree nitrogenase and hydrogenase from actinorhizal root nodules. Science 205, 688-689.

BERRY, A. \& Torrey, J. G. (1979). In Symbiotic Nitrogen Fixation in the Management of Temperate Forests, pp. 69-83. Edited by J. C. Gordon, C. T. Wheeler \& D. A. Perry. Corvallis: Oregon State University Press.

Biggins, D. R. \& Postgate, J. R. (1969). Nitrogen fixation by cultures and cell-free extracts of $\mathrm{Myco-}$ bacterium flavum 301. Journal of General Microbiology 56, 181-193.

Biggins, D. R. \& Postgate, J. R. (1971). Confusion in the taxonomy of a nitrogen-fixing bacterium currently classified as Mycobacterium flavum 301. Journal of General Microbiology 65, 119-123.

BREED, R. S. \& SMITH, N. R. (1957). Bergey's Manual of Determinative Bacteriology, 7th edn. Baltimore: Williams \& Wilkins.

Buchanan, R. E. \& Gibbons, N. E. (1974). Bergey's Manual of Determinative Bacteriology, 8 th edn. Baltimore: Williams \& Wilkins.

Callaham, D., Tredici, P. D. \& Torrey, J. G. (1978). Isolation and cultivation in vitro of the actinomycete causing nodulation in Comptonia. Science 199, 899902.

Cross, T. \& GoOdfellow, M. (1973). Taxonomy and classification of the actinomycetes. In Actinomycetales, Characteristics and Practical Importance, pp. 11-112. Edited by G. Sykes \& F A. Skinner. London \& New York: Academic Press.
DE Smedt, J. \& DE LeY, J. (1977). Intra- and intergeneric similarities of Agrobacterium ribosomal ribonucleic acid cistrons. International Journal of Systematic Bacteriology 27, 222-240.

De Smedt, J., Bauwens, M., Tytgat, R. \& De Ley, J. (1980). Intra- and inter-generic similarities of ribosomal ribonucleic acid cistrons of free-living, nitrogenfixing bacteria. International Journal of Systematic Bacteriology 30, 106-122.

GaUthier, D., Diem, H. G. \& Dommergues, Y. (1981). In vitro nitrogen fixation by two actinomycete strains isolated from Casuarina nodules. Applied and Environmental Microbiology 14, 306-308.

Gray, P. H. H. \& Thornton, H. G. (1928). Soil bacteria that decompose certain aromatic compounds. Zentralblatt für Bakteriologie, Parasitenkunde, Infectionskrankheiten und Hygiene (Abteilung II) 73, 82-84.

Hill, S. \& Postgate, J. R. (1969). Failure of putative nitrogen-fixing bacteria to fix nitrogen. Journal of General Microbiology 56, 277-285.

JONES, K. L. (1949). Fresh isolates of actinomycetes in which the presence of sporogenous aerial mycelia is a fluctuating characteristic. Journal of Bacteriology 57, 141-145.

KÜSTER, E. (1959). Outline of a comparative study of criteria used in characterisation of the actinomycetes. International Bulletin of Bacterial Nomenclature and Taxonomy 9, 97-104.

LECHEVALIER, M. P. \& LECHEVALIER, H. A. (1979). In Symbiotic Nitrogen Fixation in the Management of Temperate Forests, pp. 111-122. Edited by J. C. Gordon, C. T. Wheeler \& D. A. Perry. Corvallis: Oregon State University Press.

Malik, K. A. \& Claus, D. (1979). Xanthobacter flavus, a new species of nitrogen-fixing hydrogen bacteria. International Journal of Systematic Bacteriology 29, 283-287.

Metcalfe, G. \& Brown, M. E. (1957). Nitrogen fixation by new species of Nocardia. Journal of General Microbiology 17, 567-572.

QuisPel, A. \& TAK, T. (1978). Studies on the growth of the endophyte of Alnus glutinosa (L.) Vill. in nutrient solutions. New Phytologist 81, 587-600.

RAI, A. N. (1980). Studies on the nitrogen-fixing lichen Peltigera aphosa Willel. Ph.D. thesis, University of Dundee, U.K.

Stewart, W. D. P., Mague, T., Fitzgerald, G. P. \& BURRIS, R. H. (1971). Nitrogenase activity in Wisconsin lakes of differing degrees of eutrophication. New Phytologist 70, 497-509. 
Sukapure, R. S., Lechevalier, M. P., Reber, H., Higgins, M. L., Lechevalier, H. A. \& Prauser, H. (1970). Motile nocardial Actinomycetales. Applied Microbiology 19, 527-533.

TJEPKEMA, J. D. \& Evans, H. J. (1975). Nitrogen fixation by free-living Rhizobium in a defined liquid medium. Biochemical and Biophysical Research Communications 65, 625-628.

Tuepkema, J. D., Ormerod, W. \& Torrey, J. G. (1980). Vesicle formation and acetylene reduction activity in Frankia sp. CP11 cultured in defined nutrient media. Nature, London 287, 633-635.

Van Straten, J., Akkermans, A. D. L. \& Roelofsen, W. (1977). Nitrogenase activity of endophyte suspensions derived from root nodules of Alnus, Hippophae, Shepherdia and Myrica spp. Nature, London 266, 257-258.

Wellington, E. M. H. \& Williams, S. T. (1978). Preservation of actinomycete inoculum in frozen glycerol. Microbios Letters 6, 151-157. 